\title{
Does Migration Pay Off in Later Life? Income and Subjective Well-Being of Older Migrants in Europe
}

\author{
Stefan Gruber $^{1}$ D . Gregor Sand ${ }^{1}$
}

Accepted: 21 September 2020 / Published online: 7 October 2020

(c) The Author(s) 2020

\begin{abstract}
This study examines whether intra-European migration pays off in terms of income and subjective well-being (SWB) for migrants aged 50+ who are now growing old abroad and in what way their SWB is associated with their relative income position. Using panel data from the Survey of Health, Ageing and Retirement in Europe allows us to go beyond the classical comparison with the native reference group and draw on information about respondents who stayed in the place of origin ('stayers'). Our findings indicate that migration does pay off in later life. Compared to similar stayers, migrants have higher income and higher SWB levels. Furthermore, we find that older migrants' SWB is positively associated with their relative income position for those with an income above the income of both stayers in the origin and natives in the destination country.
\end{abstract}

Keywords Migration · Aging $\cdot$ Subjective well-being $\cdot$ CASP $\cdot$ Relative income $\cdot$ SHARE

\section{Introduction}

Within the last decades, an ever-growing number of people all over Europe have settled down in places other than their places of origin. Even though the individual driving forces of migration may differ, the majority of persons who migrate to another country share a common goal: the improvement of their economic living conditions and their well-being. Many intra-European migrants have resided in their destination already for a considerable amount of time. To date, we know little about how these migrants fare in later life. Since the share of migrants has grown continuously among the older population in many countries of the Western hemisphere, migration and aging have become two intertwined research topics (King et al. 2017). As King et al. (2014) note, too little research exists exploring the 'intersectionalities' of aging, including those emerging in a migratory setting.

Stefan Gruber

gruber@mea.mpisoc.mpg.de

Gregor Sand

sand@mea.mpisoc.mpg.de

1 Max Planck Institute for Social Law and Social Policy, Munich Center for the Economics of Aging, Amalienstrasse 33, 80799 Munich, Germany 
Studying the economic situation and the well-being of the increasing number of older migrants living abroad may serve policy makers to improve and streamline integration policies across Europe. The consequences of moving to another country do not only have an individual but also a societal dimension. Migrants who are satisfied with their living conditions identify more with their destination and acculturate better (Richardson 1967). Additionally, they show more positive attitudes and habits towards the destination country (Johnson and Fredrickson 2005), generally contribute more to society (De Neve et al. 2013), and are less likely to be dependent on the destination country's welfare and healthcare system (Ivlevs 2014). The last aspect becomes especially relevant in later life.

A great share of the extant literature focuses on the economic performance of younger and recently arrived migrants (e.g., Kogan 2011; Fleischmann and Dronkers 2010; van Tubergen et al. 2004). Concerning the financial benefits from migration, Clemens et al. (2008) find a wage gap of $\$ 15,400$ per year for an average male migrant who moved from a developing country to the US. Nikolova and Graham (2014) focus on migration from transition and post-transition countries to different destinations and find an 'unequivocal' increase in migrants' household income. Whether migrants exhibit such income advantages also in later life has not been explored so far.

A growing number of social scientists have given attention to how moving to another country affects the non-economic aspects of migrants' lives such as happiness and subjective well-being (SWB). With some exceptions for certain migrant groups, the trend in research on migrants' SWB is as follows. Studies that are confined to their destination countries and use the native population as reference group find lower SWB among migrants. Tucci et al. (2014) find such an immigrant-native gap in SWB for immigrants to Germany. Safi (2010) detects this gap for both first and second-generation migrants in 13 different European destination countries. A recent study by Hendriks and Burger (2019) relates unsuccessful SWB assimilation among immigrants in different European destinations to their faltering perceptions of the host society. Bartram (2011) finds that migrants in the US report lower levels of happiness than US-born natives. An immigrant-native gap in SWB was also found in the few existing studies that focus on older migrants aged 50 and above (Sand and Gruber 2016; Amit and Litwin 2010). In contrast, studies that include non-migrants in the origin countries (from now on stayers) as reference group detect higher SWB levels among migrants. By comparing Turkish migrants and stayers, BaykaraKrumme and Platt (2018) find a positive effect of migration on life satisfaction in later life. According to Bartram (2013), Eastern European migrants generally appear to be happier than those who have remained in the countries of origin. However, his results indicate that this difference is the result of a selection bias. With some significant variation by origin country, people who decide to migrate tend to have higher levels of happiness. For different origin contexts, Nikolova and Graham (2014) find that migration not only increases migrants' absolute income but also enhances their SWB.

Research that looks at the connection between economic factors and well-being and that uses macro-level indicators such as GDP or GINI finds diminishing SWB gains over time despite of increasing income levels (e.g., Alesina et al. 2004; Easterlin 2001, 1974). From research using micro-level indicators we know that once individuals' financial needs are met, their happiness depends much more on the relative perception of their income in comparison to others. Di Tella et al. (2010) explore the vanishing effect of income on SWB over time. They find that 65 percent of the current year's impact of income on SWB is lost over the following four years. For different European countries, the Leyden Group finds that a current increase of one dollar in the household income drops to an experienced increase of 60 cents in peoples' income evaluation after about two years (van Praag and Frijters 1999). An important 
implication of these findings is that the time of observation is an important factor. If individuals are observed right after an income gain, a different income effect on SWB is measured than several years later.

Many researchers have stressed the role of the relative income position for individual SWB (e.g., Easterlin 1974). In this context, migrants are an interesting population as they are confronted with two possible reference groups: natives in the new destination country and stayers in the origin country. Gokdemir and Dumludag (2012) examine the role of the income of Turkish and Moroccan immigrants to the Netherlands compared to the native population. They find a significant association between relative income and happiness. Studying the main migrant groups in Germany, a study by Akay et al. (2017) shows that their origin countries act as a "natural comparator" for migrants. They assert that the economic situation in the place of origin relative to the economic situation in the place of destination plays a decisive role in determining the SWB levels of migrants. Migrants' SWB decreases with increasing GDP per capita of the origin country. However, the authors argue that the importance of the country of origin declines with duration of stay and the degree of assimilation. Another study by Melzer and Muffels (2017) examines the link between migrants' individual income and SWB. The authors focus on intra-German East-West migration after the German reunification. They find that even though migrants' SWB increases after migration, among male migrants, these SWB gains are diminished by dissatisfaction resulting from income comparisons with the new reference group in Western Germany.

Hence, the time of observation and a change in the reference group appear to be major factors in the nexus between income, SWB, and migration. While shortly after migration, those who remained in the place of origin represent the main reference point for migrants, over time the new peers in the place of destination become the main comparison group-at least as an additional point of reference (Melzer and Muffels 2017). According to Aberg Yngwe et al. (2003), there is no theoretical or empirical consensus neither on the social comparison process itself nor on the nature of the reference group. In this regard, Diener et al. (1993) state that "we cannot be sure that people compare themselves to neighbors or to racially similar others. We cannot be sure that people do not compare across national boundaries." However, results by Bygren (2004) indicate that people compare themselves rather to broader social categories than specific groups. For instance, national and occupational pay reference levels are most important for pay satisfaction.

With this study, we contribute to the literature that looks at the nexus between income, $\mathrm{SWB}$, and migration. The aim is to explore whether migration pays off both in terms of income and subjective well-being for migrants aged 50+who moved from one European country to another European country at some point in their life and are now growing old abroad. In particular, we focus on the impact of the relative income position on the SWB of older migrants. Using data from the Survey of Health, Ageing and Retirement in Europe (SHARE) allows us to explore the benefits of migration by drawing on information about respondents who stayed in the place of origin ('stayers'). By choosing a measure of SWB that combines several aspects of the quality of life of older people, we go beyond the usage of unidimensional SWB indicators. 


\section{Theoretical Approach}

People produce and maximize their well-being based on the physical, material, financial, or social resources and constraints they face (Lindenberg 2001; Allardt 1993). Several theories on international migration assume that migration is an investment into future living conditions, where the returns to individual human capital are expected to exceed the costs of migration in the long run (e.g., neoclassical models, rational choice models, human capital theory, new economics of labor migration). Migrants usually move to those countries that maximize their well-being-mostly from less to more developed countries (e.g., Melzer and Muffels 2017; Gokdemir and Dumludag 2012). According to the standard individual-level migration model developed by Sjaastad (1962), the migration decision is based on a cost-benefit calculation. The costs include direct expenses such as transportation costs, language courses, and visa fees; opportunity costs of foregone earnings and opportunities at home; as well as psychological costs related to separation from family and friends (Nikolova and Graham 2014). Since the reference point of many migrants' actions is the improvement of their living conditions, the main benefits of migration are the expected earnings at the place of destination (Davis and Winters 2001).

H1: We assume the economic benefits to exceed the economic costs and expect higher absolute income levels among migrants compared to stayers in the origin country.

Apart from that, non-pecuniary indicators are useful to represent individual utility (Clark et al. 2008). While income reflects the objectively measurable economic benefits, SWB represents the subjectively perceived welfare benefits of migration. The set point theory of well-being argues that individuals' SWB levels are relatively constant and that life events only lead to temporary shifts (Lykken and Tellegen 1996). However, recent literature provides evidence that certain life events lead to large, long-term changes in the set point (e.g., Lucas 2007; Headey 2007). The question is whether migration is such a life event with long-lasting consequences for a person's SWB and whether the consequences are positive or negative. To observe individual changes in SWB through migration, it would be necessary to draw on pre-migration data that allow for within-comparisons. However, in the absence of pre-migration data, between-comparisons of migrants' postmigration SWB with corresponding values of stayers in the origin country can make the costs or benefits of migration more tangible. On the one hand, migrants might be worse off due to so-called 'acculturative stress' (Berry 1997), which might have a negative effect on individual SWB. On the other hand, an improvement of the (economic) living conditions through migration might lead to higher SWB levels among migrants. Again, we expect the SWB benefits to exceed the costs.

H2: We expect higher SWB levels among migrants compared to stayers in the origin country.

Income and SWB are positively associated with each other (e.g., Kahneman and Deaton 2010; Clark et al. 2008; Stevenson and Wolfers 2008). According to the relative standards approach, "people with comparable income (and presumably, the same level of satisfaction of innate needs), may be happy or unhappy depending on their past income or the wealth of those around" (Diener et al. 1993, p. 196). Therefore, the association between income and SWB is not only based on personal income gains in terms of an absolute 
income increase (absolute income hypothesis), but also on social comparison processes in terms of the acquired relative income position (relative income hypothesis) (Diener et al. 2018; Karlsson et al. 2010; Festinger 1954). In other words, within a given country, people develop certain standards that are changeable across place and time (e.g., their desired income). These standards represent internal and/or external reference points. An internal reference point refers to the comparison of an individual to oneself (within-comparison), either to one's own past income (adaptation) or to one's expected/desired future income (aspirations). Adaptation means that individuals get used to their circumstances, insofar as changes in absolute income and SWB describe a curvilinear trend. The same applies to growing aspirations. If aspirations rise with own actual income, then the impact of income on SWB is muted (Clark et al. 2008; Easterlin 2001, 1974; Veenhoven 1991). An external reference point refers to the social comparison of an individual with proximal others (between-comparison), for instance with a distinct demographic group such as the social network, colleagues at the workplace, or objective social indicators such as wage levels (Festinger 1954). Since we apply between-comparisons, external reference points are central for this study.

In line with the new economics of labor migration approach by Stark (1991), the acquired relative income position in the destination could be more important for migrants' SWB than the absolute income increase they may have experienced shortly after moving abroad. Stark argues that if migrants do not attain the expected increase in relative income, their disappointment through shifting the frame of reference over time can diminish or consume all potential SWB gains. This means that migrants with a long duration of stay in the place of destination evaluate their lives based on the gap between their expected and their actually achieved income position relative to the native population in the destination.

H3: As we observe older migrants with a long duration of stay, we expect that their SWB is positively associated with their relative income position in the destination country.

\section{Data and Methods}

\subsection{Database}

We analyze data from the Survey of Health, Ageing and Retirement in Europe (SHARE), a multidisciplinary and cross-national panel database of microdata on health, socio-economic status, and social and family networks of persons aged 50 and above (Börsch-Supan et al. 2013). We use a pooled sample of waves 1, 2, 4, 5, 6, and 7 of SHARE release 7.0.0 covering the time between 2004 and 2017 (Börsch-Supan 2017). Wave 3 and the parts of Wave 7 that focus on retrospective life histories are excluded because of a different content and data structure. Due to the variety of countries and the large amount of respondents, the income and well-being of intra-European migrants can be compared to data from respondents in the origin countries.

Our sample includes the largest intra-European migrant groups available in SHARE. We define migrants as respondents who were born in another country than their current country of residence. Stayers are defined as respondents who were born and still live in the respective origin country. As our focus is not on international retirement migration, we exclude all observations of persons who migrated around retirement age (63 or above; $n=39)$ and those with missing information on age at migration $(n=72)$. Overall, the sample contains 
162,437 observations from stayers and 5,435 observations from migrants originating from Austria (AT), Belgium (BE), Switzerland (CH), the Czech Republic (CZ), Germany (DE), Denmark (DK), Spain (ES), France (FR), Croatia (HR), Italy (IT), the Netherlands (NL), Poland (PL), Portugal (PT), Sweden (SE), or Slovenia (SI). The main migration flows captured in the sample can be seen in Table 3 of the appendix. The largest share of migrants is from Germany and Italy, the main destinations are Belgium, Germany, France, Luxembourg, and Switzerland. Please note that due to the very low number of migrants originating from Luxembourg, this country is only included as destination.

\subsection{Dependent, Explanatory, and Control Variables}

We use two dependent variables to measure the real economic and self-perceived welfare benefits of migration. First, we estimate absolute income by taking the PPP-adjusted yearly household net income. We choose a natural log transformation to compensate for the skewness of our income data. To control for wealth differences, we use an inverse hyperbolic sine transformation of our measure of wealth that includes household gross financial assets (i.e., bank accounts, stocks and bonds, savings for long-term investments, financial liabilities), household real assets (e.g., complete or partial house or business ownerships, cars, mortgages), at the same time accounting for any kind of debts. Both measures are adjusted to the (unweighted) number of persons living in the household at each time of observation. In order to maximize the number of observations, we take the imputed versions for income and wealth as provided by SHARE. Wealth is included in the models to assure that the income (dis-)advantages are not distorted by the accumulation of property.

Second, we operationalize SWB via the CASP index. It should be noted that there is no consistent definition and operationalization of SWB measures in the literature (see also Hyde et al. 2003). This may be due to the strong correlation of SWB measures with each other (Sobel, Semyonov, and Lewin-Epstein 2019). Our measure integrates both hedonic and eudaimonic components of well-being. Hedonic components represent the cognitive, affective, and emotional aspects of well-being (Sobel, Semyonov, and Lewin-Epstein 2019; Amit and Litwin 2010; Diener and Suh 1999; Diener et al. 1985). Eudaimonic components refer to experiences that are good for oneself and relate to aspects that improve people's quality of life such as self-realization, autonomy, determination, meaningfulness, and activities that are congruent with one's values (Ryan and Deci 2001; Sobel, Semyonov, and Lewin-Epstein 2019). Apart from its multidimensional nature, an additional advantage of CASP is that it was specifically developed to quantify the SWB of older people (Sobel, Semyonov, and Lewin-Epstein 2019; Sim et al. 2011; Hyde et al. 2003). SHARE contains an abridged version of the CASP index that encompasses 12 out of originally 19 items by reducing each of the domains to the three strongest items (see also Wiggins et al. 2008; von dem Knesebeck et al. 2005). In their validation study, Sim et al. (2011) found that - despite of the scale reduction - the revised version of CASP achieved a better fit for older populations of various age groups and environments. The CASP scale includes four subscales with questions concerning the domains control, autonomy, self-realization, and pleasure (CASP). The subscale control captures people's ability to intervene in their environment. Autonomy measures to what extent people can act independently and freely. Self-realization and pleasure cover activities to achieve personal goals that make people happy (Sim et al. 2011; Hyde et al. 2003). The sum score has a minimum of 12 and a maximum of 48 and contains all 12 items listed in Table 4 of the appendix. 
For the measurement of the relative income position of migrants, we generate a variable that splits all observations of the migrant sample into four income groups: (1) income below the reference income of stayers in the origin country and natives in the destination country $(n=1,380),(2)$ income higher than stayers but lower than natives $(n=1,376),(3)$ income below stayers but above natives $(n=238)$, and (4) income equal to or above the reference income of stayers and natives $(n=2,441)$. Following the approach of Ferrer-iCarbonell (2005), we define the income of the reference group (i.e., reference income or comparison income) as the income of a respondent's peer group with similar characteristics. In our sample, it is constructed by taking the mean income values per education level (primary, secondary, tertiary) and employment status (retired vs. not retired) at a given time (i.e., wave) and place (i.e., corresponding origin or destination country).

As control variables, we include all relevant microlevel determinants on migrants' SWB mentioned in the literature (e.g., Paparusso 2019; Bartram 2013; Amit and Litwin 2010). These are age and its functional form due to the curvilinear relationship of SWB and age (e.g., Frijters and Beatton 2012); sex; marital status; having children; household size; number of years spent in education; employment status; and self-rated health status. We control for wealth in the income model and additionally for income in the SWB models. According to Akay et al. (2017), the degree of assimilation is a crucial migration-specific determinant of SWB. In our migrant sample, we therefore include a binary variable that indicates whether a person has acquired the destination country's citizenship. A dummy variable for having migrated before or after the age of 18 captures whether migrants' primary and secondary education took place in the origin or the destination context. Apart from that, the models contain wave-fixed effects and both origin country and destination country fixed effects.

\section{Methods}

We first apply random effects regression models (RE) with individual-level clustered standard errors to measure the impact of migration by taking the group difference between migrants and stayers with regard to the outcome measures. The basic model can be specified as:

$$
\gamma_{i t}=\alpha+[\text { income }]+\text { wealth }_{i t}+\beta x_{i t}+u_{i t}+\varepsilon_{i t}
$$

The outcome $\gamma_{\text {it }}$ represents income/SWB of individual i at time $\mathrm{t} ; \alpha$ describes the intercept; $\beta$ is the coefficient for the covariates $\mathrm{x}$ measured for individual $\mathrm{i}$ at time $\mathrm{t}$ (including wealth in the income model and additionally income in the SWB model); $\mathrm{u}$ and $\varepsilon$ describe the between- and within-entity error terms.

Next, by restricting our analysis to the migrant sample, we examine the association of income, wealth, and the relative income position with migrants' SWB. Therefore, we stepwise add (1) income, (2) wealth, (3) and the relative income position measured by the income group variable that describes if a respondent's income is lower or higher than or between the income of the two reference groups in the origin and the destination country. These models can be specified as:

$$
\mathrm{CASP}_{\text {it }}=\alpha+\text { income }_{\text {it }}+\text { wealth }_{\text {it }}+\text { relative income position }_{\text {it }}+\beta \mathrm{x}_{\mathrm{it}}+\mathrm{u}_{\mathrm{it}}+\varepsilon_{\mathrm{it}}
$$

In order to examine the effect of an improvement of the relative income position and to find out which reference group is more decisive for migrants' SWB, we take advantage 
of the panel data structure of SHARE and apply fixed effects (FE) models. These rule out time-constant unobserved heterogeneity between individuals by measuring the changes within individuals (Brüderl and Ludwig 2015). We consider both upward income transitions from a lower to a higher income group $(n=509)$ and downward income transitions from a higher to a lower group $(n=543)$. The FE models can be written as:

$$
\gamma_{i t}-\bar{\gamma}_{i}=\left(x_{i t}-\bar{x}_{i}\right) \beta+\left(\varepsilon_{i t}-\bar{\varepsilon}_{i}\right)
$$

$\gamma_{\mathrm{it}}$ represents the value of the CASP index observed for individual $\mathrm{i}$ at time $\mathrm{t}$; $\mathrm{x}_{\mathrm{it}}$ includes the time-variant independent variables observed for individual i at time t: income, wealth, relative income position, age and age squared, employment status, subjective health, household size and dummies for each wave of data collection. Finally, $\varepsilon$ represents the error term. Despite of running FE models, it should be taken into account that we cannot control for selection into migration. Therefore, the findings should not be interpreted causally.

\section{Results}

\subsection{Descriptives}

Figures 1 and 2 display the variation in the two outcome measures for migrants and stayers per origin country. In terms of average income, migrants are always better off than stayers, except if they were born in Switzerland or Belgium. Looking at CASP, the trend is similar, but less pronounced. While migrants originating from countries such as the Czech Republic, Croatia, Italy, and Portugal have considerably higher mean values of CASP than stayers, there is no difference for Austria, Denmark, or Sweden. Stayers in the Netherlands, Slovenia, and Switzerland even have a small CASP advantage over their migrated counterparts.

Table 1 presents descriptive statistics for stayers and migrants. Overall, migrants' average income and SWB levels are significantly higher than the ones of stayers. In terms of wealth, migrants fare significantly better than stayers as well. Regarding the relative income position, while 25 percent of migrants have an income below the reference income of stayers and natives, 45 percent have an income equal or above the income of both reference groups. Apart from that, 25 percent report an income above stayers but below natives. Finally, with about

Fig. 1 Mean values of yearly income for stayers and migrants per origin country. Source: Own calculations based on SHARE data, release 7.0 .0

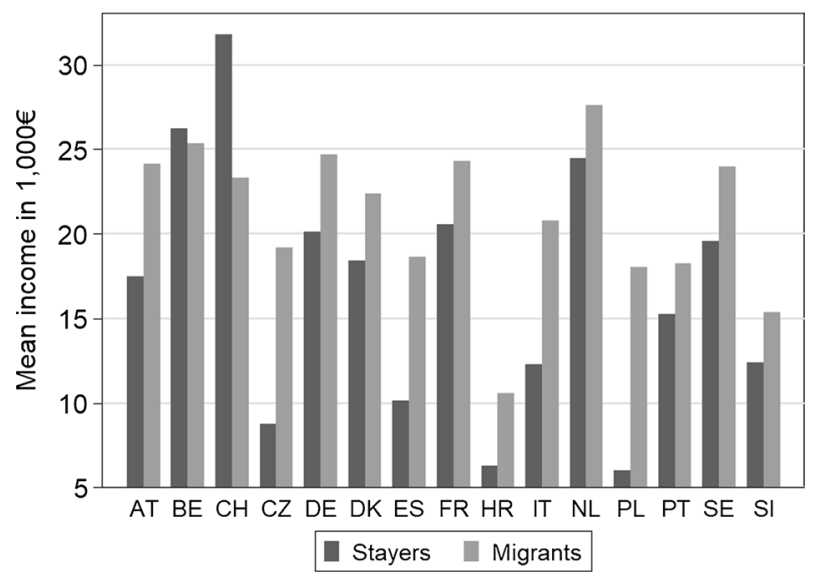


Fig. 2 Mean values of CASP for stayers and migrants per origin country. Source: Own calculations based on SHARE data, release 7.0 .0

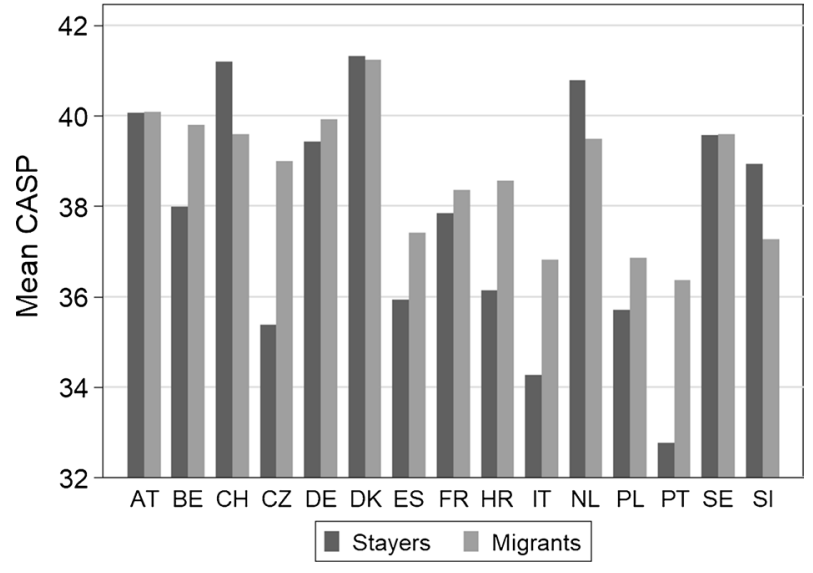

four percent a small group of respondents has a lower income than stayers but higher than natives. These are mostly migrants who moved from countries with higher income levels to countries with lower income levels, e.g. Germans in the Czech Republic, Poland, or Slovenia.

With respect to the other control variables, the proportion of female respondents is higher among migrants. We also see significant differences between migrants and stayers regarding marital status except from the percentage of widowed respondents. Having children is slightly more common among stayers. Additionally, the share of retired respondents is higher among stayers. No substantial differences between both groups are observed regarding the self-rated health status. 41 percent of the migrant sample migrated before age 18 and 60 percent acquired the destination country's citizenship.

\subsection{Regression Models}

The first set of RE regression models explore the impact of migration on absolute income and SWB (see Table 5 of the appendix). The predictive margins in Figs. 3 and 4 illustrate that migrants reach both higher income and higher CASP levels than stayers, supporting hypotheses $\mathrm{H} 1$ and $\mathrm{H} 2$.

The next analytical step restricts the sample to migrants and examines whether the relative income position within the destination is more influential for migrants' SWB in later life than their income relative to similar stayers in the origin country. This step also allows us to disentangle the influence of absolute and relative income, controlling for wealth. After stepwise including our economic indicators, we obtain the following results (see Table 2). Models 1 and 2 indicate that income and wealth have a positive influence on migrants' SWB. A comparison of model 1 and 2 shows that a greater part of the variance in SWB is explained when taking both income and wealth into account. The subsequent model adds migrants' relative income position. In Model 3 it can be seen that compared to income group 1 (income lower than stayers and natives), migrants in income group 4 (income equal to or higher than stayers and natives) report about 0.5 CASP points more $(p<0.05)$. In comparison, migrants that are divorced report about 1 CASP point less as opposed to being married or in a partnership. While the wealth coefficient remains stable, the one for absolute income becomes insignificant.

In the last step, we run FE models to explore the impact of a change in the relative income position. In contrast to the RE specification, neither changes in wealth nor absolute 
Table 1 Descriptive statistics. Source: Own calculations based on SHARE data, release 7.0.0; standard deviation in parentheses

\begin{tabular}{|c|c|c|c|}
\hline & Stayers & Migrants & Difference \\
\hline Yearly Income $(€)$ & $17,478(31,620)$ & $22,102(21,206)$ & $4,624 * * *$ \\
\hline CASP & $38.0(6.1)$ & $38.6(5.9)$ & $0.6^{* * *}$ \\
\hline Wealth (financial + real assets) $(€)$ & $296,324(494,784)$ & $424,976(724,711)$ & $128,652 * * *$ \\
\hline 1. Income $<$ stay and $<$ nat & n.a & $25.4 \%$ & - \\
\hline 2. Income $>$ stay and $<$ nat & n.a & $25.3 \%$ & - \\
\hline 3. Income $<$ stay and $>$ nat & n.a & $4.4 \%$ & - \\
\hline 4. Income $>=$ stay and $>=$ nat & n.a & $44.9 \%$ & - \\
\hline Female & $54.8 \%$ & $56,0 \%$ & $1.2^{* *}$ \\
\hline Age & $66.7(9.7)$ & $66.8(9.7)$ & 0.1 \\
\hline Years of education & $10.8(4.4)$ & $10.9(4.9)$ & 0.1 \\
\hline \multicolumn{4}{|l|}{ Marital Status } \\
\hline Married and living together (ref.) & $72.4 \%$ & $69.6 \%$ & $-2.8 * * *$ \\
\hline Separated & $1.0 \%$ & $1.8 \%$ & $0.8 * * *$ \\
\hline Never Married & $5.1 \%$ & $4.3 \%$ & $-0.8^{* *}$ \\
\hline Divorced & $7.7 \%$ & $10.2 \%$ & $2.5 * * *$ \\
\hline Widowed & $13.7 \%$ & $14.0 \%$ & 0.3 \\
\hline Having children $(y / n)$ & $90.7 \%$ & $89.8 \%$ & $-0.9 * *$ \\
\hline Household size & 2.2 & 2.1 & $-0.1 * * *$ \\
\hline \multicolumn{4}{|l|}{ Employment status } \\
\hline Retired (ref.) & $58.7 \%$ & $57.4 \%$ & $-1.3^{* *}$ \\
\hline (Self-)employed & $25.7 \%$ & $26.0 \%$ & 0.3 \\
\hline Unemployed & $2.5 \%$ & $2.5 \%$ & 0.0 \\
\hline Permanently sick / disabled & $2.8 \%$ & $3.6 \%$ & $0.8^{* *}$ \\
\hline Homemaker & $8.9 \%$ & $9.6 \%$ & $0.7^{*}$ \\
\hline Other & $1.3 \%$ & $1.0 \%$ & $-0.3 * *$ \\
\hline \multicolumn{4}{|l|}{ Self-rated health } \\
\hline Excellent (ref.) & $8.6 \%$ & $9.0 \%$ & 0.4 \\
\hline Very good & $19.2 \%$ & $19.5 \%$ & 0.3 \\
\hline Good & $38.6 \%$ & $38.4 \%$ & 0.2 \\
\hline Fair & $25.1 \%$ & $24.3 \%$ & $-0.8^{*}$ \\
\hline Poor & $8.5 \%$ & $9.0 \%$ & 0.5 \\
\hline Migration before age 18 & n.a & $41.1 \%$ & n.a \\
\hline Citizenship of destination country & n.a & $60.1 \%$ & n.a \\
\hline Number of observation & 162,437 & 5,435 & - \\
\hline Number of individuals & 71,309 & 2,809 & - \\
\hline
\end{tabular}

Significance levels obtained from t-tests; ${ }^{*} p<0.05, * * p<0.01, * * * p<0.001$

income seem to have a significant influence on SWB. However, the coefficient in Model 4 of Table 2 confirms the important role of the relative income position within the destination country. Again, only the transition into group 4 turns out to have a significant effect on migrants' well-being (0.6 CASP points; $p<0.05)$. Hence, we can conclude that even though absolute income is important, older migrants' SWB levels are mainly affected by the economic situation of their peers in the destination. This implies that their reference income in the destination is the main frame of reference. These findings confirm hypothesis H3. 
Fig. 3 Linear prediction of natural log of income of migrants compared to stayers (coefficients with $95 \%$ CIs). Source: Own calculations based on SHARE data, release 7.0.0

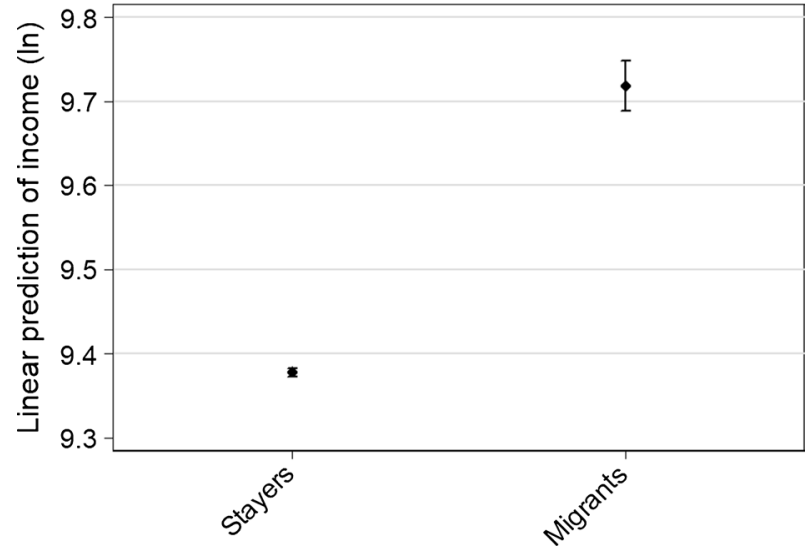

Fig. 4 Linear prediction of CASP of migrants compared to stayers (coefficients with 95\% CIs). Source: Own calculations based on SHARE data, release 7.0.0

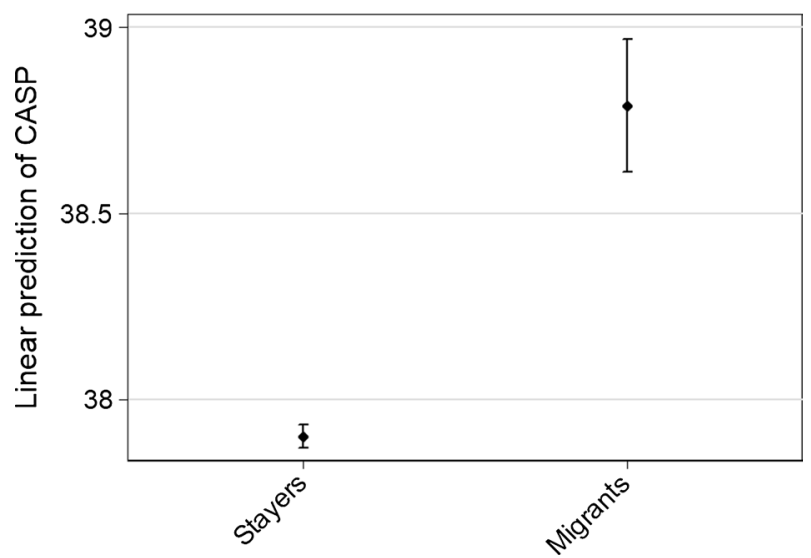

\subsection{Robustness Checks}

To check the robustness of our results, we additionally include country-wave dummies along the separate dummies for country and wave to account for cross-national disparities and time effects in the same model. This does not affect the results substantially (see Table 6 of the appendix). Moreover, we replace our dependent variable CASP with life satisfaction, a measure based on the OECD Better Life index (OECD 2013). The question wording in SHARE is: "On a scale from 0 to 10 where 0 means completely dissatisfied and 10 means completely satisfied, how satisfied are you with your life?" Our results show a different trend as for CASP. The coefficients are not significant in the RE specification and slightly significant for income group 3 (income lower than stayers but higher than natives) in the FE specification (see Table 6 of the appendix). Since this income group consists of a small number of observations, we refrain from any interpretations. Yet, it seems that the single-item measure of life satisfaction is less associated with changes in migrants' relative income position than the multi-dimensional measure CASP.

An entire series of robustness checks concerns the stepwise exclusion of specific destination and origin countries (FE specification only). Since the largest share of migrants in the sample reside in Switzerland, we first run the models excluding Switzerland as destination. The 
Table 2 Stepwise RE + FE regressions for CASP. Source: Own calculations based on SHARE data, release 7.0 .0

\begin{tabular}{|c|c|c|c|c|}
\hline & Model 1 (RE) & Model 2 (RE) & Model 3 (RE) & Model $4(\mathrm{FE})$ \\
\hline \multirow[t]{2}{*}{ Income $(\ln )$} & $0.307 * * *$ & $0.256^{* * *}$ & 0.121 & 0.125 \\
\hline & $(0.077)$ & $(0.076)$ & $(0.094)$ & $(0.113)$ \\
\hline \multirow[t]{2}{*}{ Wealth (ln) } & - & $0.243 * * *$ & $0.232 * * *$ & 0.0317 \\
\hline & - & $(0.042)$ & $(0.042)$ & $(0.063)$ \\
\hline \multirow{2}{*}{$\begin{array}{l}\text { Income group (ref.: } 1 . \\
\text { Inc }<\text { stay and < nat) }\end{array}$} & - & - & - & - \\
\hline & - & - & - & - \\
\hline \multirow[t]{2}{*}{ 2. Inc $>$ stay and $<$ nat } & - & - & -0.220 & 0.194 \\
\hline & - & - & $(0.219)$ & $(0.267)$ \\
\hline \multirow[t]{2}{*}{ 3. Inc $<$ stay and $>$ nat } & - & - & 0.163 & 0.101 \\
\hline & - & - & $(0.372)$ & $(0.416)$ \\
\hline \multirow[t]{2}{*}{ 4. Inc $\geq$ stay and $\geq$ nat } & - & - & $0.481 *$ & $0.600 *$ \\
\hline & - & - & $(0.224)$ & $(0.277)$ \\
\hline Country FE & Yes & Yes & Yes & - \\
\hline Birth country FE & Yes & Yes & Yes & - \\
\hline Wave FE & Yes & Yes & Yes & Yes \\
\hline Controls & Yes & Yes & Yes & Yes \\
\hline \multirow[t]{2}{*}{ Constant } & $23.82 * * *$ & $22.85 * * *$ & $23.89 * * *$ & -12.39 \\
\hline & $(4.398)$ & (4.398) & (4.398) & (21.076) \\
\hline$N$ & 5435 & 5435 & 5435 & 5435 \\
\hline$R^{2}$ & 0.362 & 0.373 & 0.376 & 0.061 \\
\hline
\end{tabular}

Standard errors in parentheses; $R E \mathrm{R}^{2}$ from between-estimation, $F E \mathrm{R}^{2}$ from within-estimation ${ }^{*} p<0.05, * * p<0.01, * * * p<0.001$

coefficient size for income group 4 increases to 0.7 ( $p<0.05$; see Table 7 of the appendix). This means that due to the high income levels in Switzerland, it is more difficult for migrants to reach or surpass the reference income levels of their Swiss peers. Therefore, Switzerland actually attenuates the effect size of migrants' relative income position on SWB. Germany, France, and Luxembourg belong to the main destination countries. After stepwise exclusion, the coefficient size does not change significantly (results available upon request). Finally, a bias of the results may stem from migrants' origin countries. The largest proportion of migrants originate from Germany and Italy. Both the exclusion of German migrants to Austria, Belgium, or Switzerland and the exclusion of Italian migrants to Belgium, France, Luxembourg, or Switzerland reduces the size and significance of the coefficient for income group 4 (see Table 7 of the appendix). We explain a large part of these findings by specific migration streams from countries with lower income levels to destinations with higher income levels. An improvement of the relative income position in these destinations may have a greater impact on migrants' SWB than in destinations where the income differentials compared to migrants' origin countries are smaller.

\section{Discussion and Conclusion}

In this study, we raise the question about the consequences of intra-European migration in terms of both income and subjective well-being. We use SHARE data on migrants aged $50+$ from fifteen different European origin countries who migrated to another European 
country at some point in their life and are now growing old abroad. By drawing on relative standards and social comparison theories, our study additionally focuses on the role of external reference points (measured by the relative income position) for migrants' SWB. In the absence of pre-migration data that allow for within-comparisons, we compare the postmigration outcomes of migrants to respondents with similar characteristics in the origin countries (i.e., stayers). In contrast to many other well-being studies that use unidimensional indicators, our SWB measure is CASP, a multidimensional measure that incorporates both hedonic and eudaimonic aspects of individuals' well-being. A further advantage of CASP is that it was generated specifically for respondents in later life.

Before summarizing the main results, some limitations of the applied approach should be mentioned. First, we cannot control for selection into migration. Previous findings show that persons who decide to migrate tend to have higher levels of well-being, which implies that our results cannot be interpreted causally. Second, return migration to the origin country remains unobserved. Third, our analysis does not allow for drawing conclusions about other migration contexts than the intra-European one nor about other age cohorts. Research on younger and recently arrived migrants and in different migration contexts might lead to different results.

Despite these limitations, the study contributes to the existing literature by exploring how migrants fare in later life in terms of economic and welfare benefits and how migrants' relative income position is linked with their SWB. Our first analytical step shows a clear advantage in absolute income for migrants compared to stayers in the origin country (H1). Therefore, from an economic point of view, the answer to the question whether migration pays off is affirmative. The second analytical step indicates that this also holds for migrants' SWB. Even after controlling for SWB-relevant factors, migrants report significantly higher CASP levels than stayers do (H2). In our last analytical step, we demonstrate that older long-term migrants compare themselves rather to the native reference group in the destination than to stayers in the origin country. Only having an income equal to or higher than the reference income in the destination country turns out to have a significant influence on migrants' SWB (H3). Fixed effect models underpin this finding.

To conclude, migration has consequences not only for the economic living conditions but also for the individual well-being in later life. Exploring the consequences of migration among long-term migrants that grow old abroad may serve policy makers as a blueprint to streamline current healthcare, labor market, migration, and integration policies across Europe.

Acknowledgement This paper uses data from SHARE Waves 1, 2, 4, 5, 6 and 7 (DOIs: 10.6103/SHARE. w1.700, 10.6103/SHARE.w2.700, 10.6103/SHARE.w4.700, 10.6103/SHARE.w5.700, 10.6103/SHARE. w6.700, 10.6103/SHARE.w7.700), see Börsch-Supan et al. (2013) for methodological details. The SHARE data collection has been funded by the European Commission through FP5 (QLK6-CT-2001-00360), FP6 (SHARE-I3: RII-CT-2006-062193, COMPARE: CIT5-CT-2005-028857, SHARELIFE: CIT4CT-2006-028812), FP7 (SHARE-PREP: GA N²11909, SHARE-LEAP: GA N²27822, SHARE M4: GA N ${ }^{\circ}$ 261982) and Horizon 2020 (SHARE-DEV3: GA N676536, SERISS: GA $\mathrm{N}^{\circ} 654221$ ) and by DG Employment, Social Affairs \& Inclusion. Additional funding from the German Ministry of Education and Research, the Max Planck Society for the Advancement of Science, the U.S. National Institute on Aging (U01_AG09740-13S2, P01_AG005842, P01_AG08291, P30_AG12815, R21_AG025169, Y1-AG-455301, IAG_BSR06-11, OGHA_04-064, HHSN271201300071C) and from various national funding sources is gratefully acknowledged (see www.share-project.org).

Funding Open Access funding enabled and organized by Projekt DEAL.

Open Access This article is licensed under a Creative Commons Attribution 4.0 International License, which permits use, sharing, adaptation, distribution and reproduction in any medium or format, as long as you give appropriate credit to the original author(s) and the source, provide a link to the Creative Commons licence, and indicate if changes were made. The images or other third party material in this article are included in the article's Creative Commons licence, unless indicated otherwise in a credit line to the 
material. If material is not included in the article's Creative Commons licence and your intended use is not permitted by statutory regulation or exceeds the permitted use, you will need to obtain permission directly from the copyright holder. To view a copy of this licence, visit http://creativecommons.org/licenses/by/4.0/.

\section{Appendix}

See Tables 3, 4, 5, 6 and 7 .

Table 3 Migrants' origin and main destination countries. Source: Own calculations based on SHARE data, release 7.0.0

\begin{tabular}{|c|c|c|c|}
\hline Origin country & $\begin{array}{l}\text { Number of observa- } \\
\text { tions }\end{array}$ & Main destination countries & $\begin{array}{l}\text { Number of } \\
\text { observations }\end{array}$ \\
\hline \multirow[t]{2}{*}{ Austria } & 299 & Switzerland & 136 \\
\hline & & Germany & 80 \\
\hline \multirow[t]{2}{*}{ Belgium } & 261 & Luxembourg & 125 \\
\hline & & France & 47 \\
\hline Croatia & 157 & Slovenia & 137 \\
\hline \multirow[t]{2}{*}{ Czech Republic } & 337 & Germany & 164 \\
\hline & & Austria & 99 \\
\hline Denmark & 84 & Sweden & 59 \\
\hline \multirow[t]{3}{*}{ France } & 669 & Belgium & 236 \\
\hline & & Switzerland & 198 \\
\hline & & Luxembourg & 116 \\
\hline \multirow[t]{3}{*}{ Germany } & 1335 & Switzerland & 468 \\
\hline & & Austria & 271 \\
\hline & & Belgium & 103 \\
\hline \multirow[t]{4}{*}{ Italy } & 938 & Belgium & 302 \\
\hline & & Switzerland & 209 \\
\hline & & France & 156 \\
\hline & & Luxembourg & 123 \\
\hline Netherlands & 227 & Belgium & 124 \\
\hline Poland & 342 & Germany & 171 \\
\hline \multirow[t]{2}{*}{ Portugal } & 233 & Luxembourg & 127 \\
\hline & & France & 60 \\
\hline \multirow[t]{2}{*}{ Slovenia } & 98 & Czech Republic & 35 \\
\hline & & Austria & 26 \\
\hline \multirow[t]{2}{*}{ Spain } & 265 & France & 108 \\
\hline & & Belgium & 55 \\
\hline Sweden & 89 & Denmark & 44 \\
\hline Switzerland & 101 & France & 54 \\
\hline Total & 5435 & & \\
\hline
\end{tabular}


Table 4 CASP subscales. Source: https://www.share-project.org/data-documentation/questionnaires.html

\begin{tabular}{ll}
\hline Subscale & Question text \\
\hline Control & $\begin{array}{l}\text { 1. How often do you think your age prevents you from doing the things you would like to } \\
\text { do? (Often, sometimes, rarely or never?) }\end{array}$ \\
2. How often do you feel that what happens to you is out of your control? \\
3. How often do you feel left out of things? \\
Autonomy & 1. How often do you think that you can do the things that you want to do? \\
& 2. How often do you think that family responsibilities prevent you from doing what you \\
& want to do? \\
3. How often do you think that shortage of money stops you from doing the things you \\
want to do?
\end{tabular}

Table 5 RE regressions for absolute income (ln) and CASP. Source: Own calculations based on SHARE data, release 7.0.0

\begin{tabular}{lll}
\hline & Income & CASP \\
\hline Migrants (ref. stayers) & $0.341^{* * *}$ & $0.889 * * *$ \\
Income (ln) & $(21.59)$ & $(9.61)$ \\
& - & $0.212^{* * *}$ \\
Wealth (ln) & - & $(15.08)$ \\
& $0.068 * * *$ & $0.246 * * *$ \\
Country FE & $(39.18)$ & $(29.14)$ \\
Birth country FE & Yes & Yes \\
Wave FE & Yes & Yes \\
Controls & Yes & Yes \\
Constant & Yes & Yes \\
& $8.182^{* * *}$ & $23.695 * * *$ \\
$N$ & $(57.17)$ & $(31.72)$ \\
$R^{2}$ & 167,872 & 167,872 \\
\hline
\end{tabular}

Standard errors in parentheses; $R E \mathrm{R}^{2}$ from between-estimation $* p<0.05, * * p<0.01, * * * p<0.001$ 
Table $6 \mathrm{RE}+\mathrm{FE}$ regressions for CASP (with country-wave dummies) and life satisfaction. Source: Own calculations based on SHARE data, release 7.0.0

\begin{tabular}{|c|c|c|c|}
\hline & CASP c-w (RE) & Life satisfaction (RE) & Life satisfaction $(\mathrm{FE})$ \\
\hline \multirow[t]{2}{*}{ Income (ln) } & 0.105 & -0.00456 & -0.0370 \\
\hline & $(0.097)$ & $(0.026)$ & $(0.037)$ \\
\hline \multirow[t]{2}{*}{ Wealth (ln) } & $0.234 * * *$ & $0.0352 *$ & -0.00617 \\
\hline & $(0.041)$ & $(0.014)$ & $(0.020)$ \\
\hline Income group & - & - & - \\
\hline (ref.: 1. Inc $<$ stay and $<$ nat) & - & - & - \\
\hline \multirow[t]{2}{*}{ 2. Inc $>$ stay and $<$ nat } & -0.210 & -0.0662 & -0.0330 \\
\hline & $(0.217)$ & $(0.073)$ & $(0.087)$ \\
\hline \multirow[t]{2}{*}{ 3. Inc $<$ stay and $>$ nat } & 0.0713 & 0.217 & $0.321 *$ \\
\hline & $(0.381)$ & $(0.114)$ & $(0.137)$ \\
\hline \multirow[t]{2}{*}{ 4. Inc $\geq$ stay and $\geq$ nat } & $0.502 *$ & 0.0361 & 0.0172 \\
\hline & $(0.224)$ & $(0.068)$ & $(0.091)$ \\
\hline Country FE & Yes & Yes & Yes \\
\hline Birth country FE & Yes & Yes & Yes \\
\hline Wave FE & Yes & Yes & Yes \\
\hline Country * Wave FE & Yes & No & No \\
\hline Controls & Yes & Yes & Yes \\
\hline \multirow[t]{2}{*}{ Constant } & $25.97 * * *$ & $5.965 * * *$ & 4.343 \\
\hline & (4.480) & (1.366) & (7.616) \\
\hline$N$ & 5435 & 5220 & 5220 \\
\hline$R^{2}$ & 0.377 & 0.222 & 0.024 \\
\hline
\end{tabular}

Standard errors in parentheses; $R E \mathrm{R}^{2}$ from between-estimation; $F E \mathrm{R}^{2}$ from within-estimation $* p<0.05, * * p<0.01, * * * p<0.001$ 
Table 7 FE regressions for CASP excluding high $\mathrm{N}$ countries. Source: Own calculations based on SHARE data, release 7.0.0

\begin{tabular}{llll}
\hline & CH (dest.) & DE (orig.) & IT (orig.) \\
\hline Income (ln) & 0.0910 & 0.137 & 0.267 \\
& $(0.145)$ & $(0.131)$ & $(0.136)$ \\
Wealth (ln) & 0.0566 & 0.0915 & -0.0346 \\
& $(0.099)$ & $(0.088)$ & $(0.082)$ \\
Income group & - & - & - \\
(ref.: 1. Inc $<$ stay and $<$ nat) & - & - & - \\
2. Inc $>$ stay and $<$ nat & 0.256 & 0.0128 & 0.321 \\
& $(0.357)$ & $(0.329)$ & $(0.297)$ \\
3. Inc $<$ stay and $>$ nat & 0.147 & 0.0381 & 0.0882 \\
& $(0.459)$ & $(0.546)$ & $(0.450)$ \\
4. Inc $\geq$ stay and $\geq$ nat & $0.709 *$ & 0.522 & 0.477 \\
Country FE & $(0.330)$ & $(0.343)$ & $(0.305)$ \\
Birth country FE & Yes & Yes & Yes \\
Wave FE & Yes & Yes & Yes \\
Controls & Yes & Yes & Yes \\
Constant & Yes & Yes & Yes \\
$N$ & -1.361 & -6.099 & -9.760 \\
$R^{2}$ & $(25.022)$ & $(24.511)$ & $(23.964)$ \\
\hline & 4224 & 4100 & 4497 \\
& 0.061 & 0.063 & 0.065 \\
\hline
\end{tabular}

Standard errors in parentheses; $F E \mathrm{R}^{2}$ from within-estimation ${ }^{*} p<0.05, * * p<0.01, * * * p<0.001$

\section{References}

Aberg Yngwe, M., Fritzell, J., Lundberg, O., Diderichsen, F., \& Burstrom, B. (2003). Exploring relative deprivation: Is social comparison a mechanism in the relation between income and health? Social Science \& Medicine, 57(8), 1463-1473.

Akay, A., Bargain, O., \& Zimmermann, K. F. (2017). Home sweet home. Macroeconomic conditions in home countries and the well-being of migrants. Journal of Human Resources, 52(2), 351-371.

Alesina, A., Di Tella, R., \& MacCulloch, R. (2004). Inequality and happiness: Are Europeans and Americans different? Journal of Public Economics, 88(2004), 2009-2042. https://doi.org/10.1016/j. jpubeco.2003.07.006.

Allardt, E. (1993). Having, loving, being: An Alternative to the Swedish model of welfare research. In M. Nussbaum \& A. Sen (Eds.), The quality of life (pp. 88-94). Oxford: Oxford Scholarship Online.

Amit, K., \& Litwin, H. (2010). The subjective well-being of immigrants aged 50 and older in Israel. Social Indicators Research, 98(1), 89-104. https://doi.org/10.1007/s11205-009-9519-5.

Bartram, D. (2011). Economic migration and happiness: Comparing immigrants' and natives' happiness gains from income. Social Indicators Research, 103(1), 57-76. https://doi.org/10.1007/s1120 5-010-9696-2.

Bartram, D. (2013). Happiness and 'economic migration': A comparison of Eastern European migrants and stayers. Migration Studies, 1(2), 156-175. https://doi.org/10.1093/migration/mnt006.

Baykara-Krumme, H., \& Platt, L. (2018). Life satisfaction of migrants, stayers and returnees: Reaping the fruits of migration in old age? Ageing and Society, 38(4), 721-745. https://doi.org/10.1017/ S0144686X16001227.

Berry, J. W. (1997). Immigration, acculturation, and adaptation. Applied Psychology, 46(1), 5-34.

Börsch-Supan, A. (2017). Survey of Health, Ageing and Retirement in Europe (SHARE) Wave 1, 2, 4, 5, 6 and 7. Release version: 7.0.0. SHARE-ERIC, Data set. DOIs: https://doi.org/10.6103/SHARE .w1.700, https://doi.org/10.6103/SHARE.w2.700, https://doi.org/10.6103/SHARE.w4.700, https:// 
doi.org/10.6103/SHARE.w5.700, https://doi.org/10.6103/SHARE.w6.700, https://doi.org/10.6103/ SHARE.w7.700.

Börsch-Supan, A., Brandt, M., Hunkler, C., Kneip, T., Korbmacher, J., Malter, F., et al. (2013). Data resource profile: the survey of health, ageing and retirement in Europe (SHARE). International Journal of Epidemiology, 42(4), 992-1001. https://doi.org/10.1093/ije/dyt088.

Brüderl, J., \& Ludwig, V. (2015). Fixed-effects panel regression. In H. Best \& C. Wolf (Eds.), The SAGE handbook of regression analysis and causal inference (pp. 327-357). London: SAGE Publications Ltd.

Bygren, M. (2004). Pay reference standards and pay satisfaction what do workers evaluate their pay against? Social Science Research, 33(2), 206-224. https://doi.org/10.1016/S0049-089X(03)00045-0.

Clark, A., Frijters, P., \& Shields, M. (2008). Relative income, happiness, and utility: An explanation for the Easterlin paradox and other puzzles. Journal of Economic Literature, 46(1), 95-144. https://doi. org/10.1257/jel.46.1.95.

Clemens, M. A., Montenegro, C. E., and Pritchett, L. (2008). The Place Premium: Wage Differences for Identical Workers across the Us Border. World Bank Policy Research Working Paper No. 4671.

Davis, B., \& Winters, P. (2001). Gender, networks and Mexico-US migration. The Journal of Development Studies, 38(2), 1-26.

De Neve, J. E., Diener, E., Tay, L., \& Xuereb, C. (2013). The Objective benefits of subjective well-being. New York: UN Sustainable Development Solutions Network.

Diener, E., Emmons, R. A., Larsen, R. J., \& Griffin, S. (1985). The satisfaction with life scale. Journal of personality assessment, 49(1), 71-75. https://doi.org/10.1207/s15327752jpa4901_13.

Diener, E., Sandvik, E., Seidlitz, L., \& Diener, M. (1993). The relationship between income and subjective well-being: Relative or absolute? Social Indicators Research, 28(3), 195-223. https://doi.org/10.1007/ bf01079018.

Diener, E., Suh, E. M., Lucas, R. E., \& Smith, H. L. (1999). Subjective well-being: Three decades of progress. Psychological bulletin, 125(2), 276.

Diener, E., Oishi, S., \& Tay, L. (2018). Advances in subjective well-being research. Nature Human Behaviour, 2(4), 253-260. https://doi.org/10.1038/s41562-018-0307-6.

Di Tella, R., MacCulloch, R., \& Haisken-DeNew, J. P. (2010). Happiness adaptation to income and to status in an individual panel. Journal of Economic Behavior and Organization, 76, 834-852. https://doi. org/10.1016/j.jebo.2010.09.016.

Easterlin, R. A. (1974). Does economic growth improve the human lot? some empirical evidence. In P. A. David \& M. W. Reder (Eds.), Nations and households in economic growth Essays in honor of Moses Abramovitz. NY: Academic Press.

Easterlin, R. A. (2001). Income and happiness: Towards a unified theory. The Economic Journal, 111(473), 465-484. https://doi.org/10.1111/1468-0297.00646.

Ferrer-i-Carbonell, A. (2005). Income and well-being: an empirical analysis of the comparison income effect. Journal of Public Economics, 89, 997-1019.

Festinger, L. (1954). A Theory of social comparison processes. Human Relations, 7(2), 117-140.

Fleischmann, F., \& Dronkers, J. (2010). Unemployment among immigrants in European labour markets: An analysis of origin and destination effects. Work, Employment and Society, 24(2), 337-354. https ://doi.org/10.1177/0950017010362153.

Frijters, P., \& Beatton, T. (2012). The mystery of the U-shaped relationship between happiness and age. Journal of economic Behavior and organization, 82, 525-542. https://doi.org/10.1016/j. jebo.2012.03.008.

Gokdemir, O., \& Dumludag, D. (2012). Life satisfaction among Turkish and Moroccan immigrants in the Netherlands: The role of absolute and relative income. Social Indicators Research, 106(3), 407-417.

Headey, B. (2007). The Set-point Theory of Well-being Needs Replacing - On the Brink of a Scientific Revolution? DIW Discussion Paper 753.

Hendriks, M., \& Burger, M. J. (2019). Unsuccessful subjective well-being assimilation among immigrants: The role of faltering perceptions of the host society. Journal of Happiness Studies, online first.. https://doi.org/10.1007/s10902-019-00164-0.

Hyde, M., Wiggins, R. D., Higgs, P., \& Blane, D. B. (2003). A measure of quality of life in early old age: The theory, development and properties of a needs satisfaction model (CASP-19). Aging and Mental Health, 7(3), 186-194. https://doi.org/10.1080/1360786031000101157.

Ivlevs, A. (2014). Happy moves? Assessing the impact of subjective well-being on the emigration decision. University of the West of England Economics Working Paper Series, 1402, 1-23. 
Johnson, K. J., \& Fredrickson, B. L. (2005). "We all look the same to me" positive emotions eliminate the own-race bias in face recognition. Psychological Science, 16(11), 875-881. https://doi.org/10.1 111/j.1467-9280.2005.01631.x.

Kahneman, D., \& Deaton, A. (2010). High income improves evaluation of life but not emotional wellbeing. PNAS, 107(38), 16489-16493. https://doi.org/10.1073/pnas.1011492107.

Karlsson, M., Nilsson, T., Lyttkens, C. H., \& Leeson, G. (2010). Income inequality and health: Importance of a cross-country perspective. Social Science \& Medicine, 70(6), 875-885. https://doi. org/10.1016/j.socscimed.2009.10.056.

King, R. (2014). Ageing and migration. In B. Anderson \& M. Keith (Eds.), Migration: The COMPAS anthology (pp. 108-109). Oxford: ESRC centre on migration, policy and society.

King, R., Lulle, A., Sampaio, D., \& Vullnetari, J. (2017). Unpacking the ageing-migration nexus and challenging the vulnerability trope. Journal of Ethnic and Migration Studies, 43(2), 182-198. https ://doi.org/10.1080/1369183X.2016.1238904.

Kogan, I. (2011). New immigrants - Old disadvantage patterns? Labour market integration of recent immigrants into Germany. International Migration, 49(1), 91-117. https://doi.org/10.111 1/j.1468-2435.2010.00609.x.

Lindenberg, S. (2001). Social rationality versus rational egoism. In J. H. Turner (Ed.), Handbook of sociological theory (pp. 635-668). New York: Kluwer Acadamic/Plenum Publishers.

Lucas, R. (2007). Adaptation and the set-point model of subjective well-being: Does happiness change after major life events? Current Directions in Psychological Science, 16(2), 75-79.

Lykken, D., \& Tellegen, A. (1996). Happiness is a stochastic phenomenon. Psychological Science, 7(3), 186-189.

Melzer, S. M., \& Muffels, R. J. (2017). Migrants' pursuit of happiness: An analysis of the effects of adaptation, social comparison and economic integration on subjective well-being on the basis of German panel data for 1990-2014. Migration Studies, 5(2), 190-215.

Nikolova, M., \& Graham, C. (2014). In transit: The well-being of migrants from transition and posttransition countries. IZA Discussion Paper, 8520, 1-55.

OECD. (2013). OECD guidelines on measuring subjective well-being. OECD Publishing. https://doi. org/10.1787/9789264191655-en.

Paparusso, A. (2019). Studying immigrant integration through self-reported life satisfaction in the country of residence. Applied Research in Quality of Life, 14(2), 479-505. https://doi.org/10.1007/s1148 2-018-9624-1.

Richardson, A. (1967). A theory and a method for the psychological study of assimilation. International Migration Review, 2(1), 3-30. https://doi.org/10.1177/019791836800200101.

Ryan, R. M., \& Deci, E. L. (2001). On happiness and human potentials: A review of research on hedonic and eudaimonic well-being. Annual Review of Psychology, 52, 141-166. https://doi.org/10.1146/annur ev.psych.52.1.141.

Safi, M. (2010). Immigrants‘ life satisfaction in Europe: Between assimilation and discrimination. European Sociological Review, 26(2), 159-176. https://doi.org/10.1093/esr/jcp013.

Sand, G., \& Gruber, S. (2016). Differences in subjective well-being between older migrants and natives in Europe. Journal of Immigrant and Minority Health, 20(1), 83-90.

Sim, J., Bartlam, B., \& Bernard, M. (2011). The CASP-19 as a measure of quality of life in old age: Evaluation of its use in a retirement community. Quality of Life Research, 20(7), 997-1004. https://doi. org/10.1007/s11136-010-9835-x.

Sjaastad, L. A. (1962). The costs and returns of human migration. Journal of Political Economy, 70(5), 80-93.

Sobel, I., Semyonov, M., \& Lewin-Epstein, N. (2019). The dynamic relationship between wealth and subjective well-being among mid-life and older adults in Israel. In G. Brulé \& C. Suter (Eds.), Wealth(s) and subjective well-being (pp. 415-442). Cham: Springer International Publishing.

Stark, O. (1991). The migration of labor. Camebridge: Blackwell.

Stevenson, B. and Wolfers, J. (2008). Economic Growth and Subjective Well-Being: Reassessing the Easterlin Paradox. NBER Working Paper No. 14282. https://www.nber.org/papers/w14282.pdf.

Tucci, I., Eisnecker, P., \& Brücker, H. (2014). Wie zufrieden sind Migranten mit ihrem Leben? DIWWochenbericht, 81(43), 1152-1158.

Van Praag, B. M. S., \& Frijters, P. (1999). The measurement of welfare and well-being: The Leyden approach. In D. Kahneman, E. Diener, \& N. Schwarz (Eds.), Foundations of hedonic psychology: Scientific perspectives on enjoyment and suffering (pp. 413-433). New York: Russell Sage Foundation.

Van Tubergen, F., Maas, I., \& Flap, H. (2004). The economic incorporation of immigrants in 18 Western societies: Origin, destination, and community effects. American Sociological Review, 69(5), 704-727. 
Veenhoven, R. (1991). Is happiness relative? Social Indicators Research, 24(1), 1-34. https://doi. org/10.1007/bf00292648.

Von dem Knesebeck, O., Hyde, M., Higgs, P., Kupfer, A., \& Siegrist, J. (2005). Quality of life and wellbeing. In A. Börsch-Supan, A. Brugiavini, H. Jürges, J. Mackenbach, J. Siegrist, \& G. Weber (Eds.), Health, ageing and retirement in Europe - First results from the survey of health, ageing and retirement in Europe (pp. 101-109). Mannheim: Mannheim Research Institute for the Economics of Aging (MEA).

Wiggins, R. D., Netuveli, G., Hyde, M., Higgs, P., \& Blane, D. (2008). The evaluation of a self-enumerated scale of quality of life (CASP-19) in the context of research on ageing: A combination of exploratory and confirmatory approaches. Social Indicators Research, 89, 61-77.

Publisher's Note Springer Nature remains neutral with regard to jurisdictional claims in published maps and institutional affiliations. 